\title{
Determination of Heavy Metals in 16 Bleaching Creams and 3 Mixtures of Bleaching Creams from Local Market of Jeddah
}

\section{Faten M. Zainy}

Department of Chemistry, Faculty of Science, Alfaisaliah Campus, King Abdulaziz University, Jeddah, Saudi Arabia.

\begin{abstract}
H EAVY metals on bleaching cream products easy cased many types of skin problems and deleterious effects to the human health. Many consumers are using mixture of bleaching creams simultaneously to get a double activity (shiny and faster) on their skins. They are at risk of toxicity and adverse interactions due to their multiplicative contamination with heavy metals and uncertain mixing of different components. 16 bleaching creams and 3 mixtures of bleaching creams were digested with high pressure microwave technique followed by injection on Inductive Coupled Plasma Optical Emission Spectrometer (ICP-OES) for determining ( $\mathrm{Hg}, \mathrm{Cd}$, $\mathrm{Ti}, \mathrm{Bi}, \mathrm{Pd}, \mathrm{As}$ and $\mathrm{Tl}$ ) elements. The obtained results showed that, the highest concentration for $(\mathrm{Hg}, \mathrm{Bi}, \mathrm{Ti}$ and $\mathrm{Pb})$ on samples were 5739.16, 7013.53, 21407.73, $456.70 \mathrm{ppm}$, respectively, other metals less than $28.99 \mathrm{ppm}$. One of the mixtures sample has high concentrations of $\mathrm{Hg}$ and $\mathrm{Bi}$ were $13338.50,619.23 \mathrm{ppm}$, respectively, so creams and its mixtures which contain heavy metals above the permissible limit must be blind. Detection limits are achieved at the level of $2.5-50 \mu \mathrm{g} / \mathrm{g}$, RSD were less than $14.72 \%$, the recoveries for cosmetics were in the range of $88.52 \%$ to $99.62 \%$. Good results show that the method is quick, accurate and convenient.
\end{abstract}

Keywords: Bleaching cream, Cosmetics, Heavy metals, ICP-OES and High pressure microwave technique.

Cosmetic products since the dawn of civilization ${ }^{(1)}$ were considered as a part of routine body care. During the last few decades these products had a big boost ${ }^{(2)}$ and applied to the human body for beautification. These cosmetic products include, care creams, talcum and face powders, lipsticks, kajal, sindoor, eye makeup, mouthwashes ..., etc. ${ }^{(3)}$. Dermal exposure was expected to be the most significant route because most of the cosmetic products were directly applied to the skin. Oral exposure can occur from wearing of cosmetic products containing heavy metal impurities around the mouth and also from hand to mouth contact ${ }^{(4)}$. Examining the notices of recall in the U.S. for products manufactured in various parts of the world showed that a number of items which have been recalled are cosmetics. For example, skin whitening cream from several Caribbean countries was put on an import alert because the level of mercury measured in the product 
was $8 \%{ }^{(5)}$. Apart from the demand of availability of cosmetic products in markets, the health awareness draws the attention of researcher and clinician ${ }^{(6)}$ to find the adverse effects regarding heavy metal contamination ${ }^{(7,8)}$. Metals have been used as instruments of murder and were sprayed by the British in World War $1^{(9)}$. Generally heavy metals are those their densitie were five times greater than the density of water ${ }^{(10,11)}$. These include: antimony, arsenic, bismuth, cadmium, cerium, chromium, cobalt, copper, gallium, gold, iron, lead, manganese, mercury, nickel, platinum, silver, tellurium, thallium, tin, uranium, vanadium and zinc. Even the essential metals when present in higher concentration become toxic ${ }^{(11)}$. The heavy metal ions when come in contact with human body, get absorbed and form complexes with carboxylic acid $(-\mathrm{COOH})$, amine $\left(-\mathrm{NH}_{2}\right)$, and thiol $(-\mathrm{SH})$ of proteins resulting in malfunctioning or death of the cells and consequently lead to a variety of diseases. Treatment of metal intoxication was achieved by using a chelating agent (i.e. chelation therapy) that binds with the metal ions and the complexes are then eliminated from the body $^{(12)}$. Some cosmetics are benign; others can cause or supposed to cause harmful effects such as cancer, allergic reaction, mutations, respiratory problems as well as development and reproductive problems ${ }^{(13)}$. The presence of heavy metals in cosmetics can cause serious problems to consumer as they can cause premature aging of the skin, skin allergies, and skin cancer. Further, toxic metals have a role to set up conditions that lead to inflammation in arteries and tissues, results in osteoporosis ${ }^{(14)}$. Information on the exposure to metal toxins through dermal contact is very scanty, and few data exist on the personal care products ${ }^{(15)}$. For instance, an increased level of cadmium has been reported to cause inhibition of DNA mismatches. Zinc has been reported to cause the same signs of illness as does lead, and can easily be mistakenly diagnosed as lead poisoning ${ }^{(16)}$. Exposure to a large dose of arsenic causes skin cancer, lung cancer and pigmentation of $\operatorname{skin}^{(17,18)}$. Knowing the toxicity the (US FDA) bans nine ingredients including coal tar colors, formaldehyde, glycol ethers, lead, mercury, parabens, phenylenediamine, phthalates in cosmetic products ${ }^{(19)}$. The regulations in Canada include statements about heavy metals, and although low concentrations may be difficult to avoid, concentrations above the following levels require special scrutiny: Lead (10 mg/kg), Arsenic (3 mg/kg), Cadmium (3 $\mathrm{mg} / \mathrm{kg}$ ), Mercury (3 mg/kg) and Antimony (5 mg/kg) ${ }^{(20)}$.

The European Union (EU) has also developed a list of more than 1000 compounds that are banned for use in cosmetic manufacturing ${ }^{(21)}$. According to SASO//1953/2005, many heavy metals prohibited in any amount in cosmetics: arsenic or its compounds, cadmium or its compounds, lead or its compounds except lead acetate, mercury or some compounds and thallium or its compounds ${ }^{(22)}$. Bismuth metal most dingers, FDA wariness to use bismacine drug which contains large quantity of bismuth (23) it causes many death cases. Titanium used on cosmetic as titanium dioxide to protect the skin from ultraviolet radiation. On this paper, there is a questioner study was done on 54 ladies who use different bleaching creams on their faces and bodies. $48 \%$ of them get different problems on their skin (redness, acne, pigmentation and allergies). The study shows 11 ladies use mixture of bleaching creams to increase the activity (fast and shiny) but $36 \%$ of

Egypt. J. Chem. 58, No. 3 (2015) 
them get many problem on their skin. To provide customers with safe cosmetics, it's necessary to manage the amount of heavy metals used in cosmetic products. This application note will evaluate the levels of several heavy metals $(\mathrm{Hg}, \mathrm{Cd}, \mathrm{Ti}$, $\mathrm{Bi}, \mathrm{Pd}, \mathrm{AS}$ and $\mathrm{Tl}$ ) on 16 bleaching creams and 3 mixtures of bleaching cream's, compare results with the permissible limits of SASO (Saudi Standards, Metrology and Quality Org.) and WHO (World Health Organization). Using the inductively coupled plasma optical emission spectroscopy (ICP-OES) would be simple, reliable, sensitive and convenient.

\section{Materials and Methods}

\section{Samples collection}

According to statistic studies on 54 Saudi ladies to collect information about the most bleaching creams they favored, sixteen samples of marketed cosmetic creams were collected from local market of Jeddah. The brand names were blinded and given the codes B1 to B16. Also, according to statistic studies, 12 sales men from different cosmetic markets show three mixtures of bleaching creams which mix to increase the effect of action that given the codes B21, B22 and B23.

\section{Instruments}

Inductive coupled plasma - Optical emission spectrometer Optima 8300 PerkinElmer, Milestone ETHOS labstation with easyWAVE or easyCONTROL software HPR1000/10S high pressure segmented rotor. The instrumental conditions: read delay time ( $\mathrm{sec}$ ): 10:00, sample flush time ( $\mathrm{sec}$ ): 20:00, flow rate: $1 \mathrm{ml} / \mathrm{min}$, replicates: 3 times, wash: between sample, wash rate $(\mathrm{ml} / \mathrm{min})$ : 2:00, wash time (sec): 2:00, resolution: normal.

\section{Chemicals}

Sulphuric acid $\left(\mathrm{H}_{2} \mathrm{SO}_{4} 98 \%\right)$ and hydrogen fluoride acid ( $\left.\mathrm{HF} 40 \%\right)$ were of analytical grade (E. Merck). The water used in all experiment was ultrapure water obtained from PURELAB classic purification system (ELGA, UK). The standard solutions were prepared on five different concentrations to obtain calibration curve by diluting stock solutions: $\mathrm{Hg}, 1000 \mathrm{mg} / \mathrm{L}$ (Accu Trace $^{\mathrm{TM}}$ Reference Standard), Bi, 1000 mg/L (Accu Trace ${ }^{\mathrm{TM}}$ Reference Standard), Multi elements Cd,As, Pb, Tl and Ti, 1000 mg/L (PerkinElmer Pure).

\section{Sample preparation}

This method provides for the acid digestion of cosmetic components sample in a closed vessel device using temperature control microwave heating for the metal determination by spectroscopic methods. Place a TFM vessel on the balance plate, tare it and weigh of $0.2 \mathrm{~g}$ of. Avoid contact with the side of the vessel. Add $6 \mathrm{ml}$ of $\mathrm{H}_{2} \mathrm{SO}_{4} 98 \%$ and $2 \mathrm{ml}$ of $\mathrm{HF} 40 \%$ by using graduated pipette. If part of the sample stays on the inner wall of the TFM vessel, wet it by adding acids drop by drop, then gently swirl the solution to homogenize the sample with the acids ${ }^{(24)}$.

Digest in microwave digestion system at the specified program as follows:

$\begin{array}{llll}\text { Step } & \text { Time } & \text { Temperature } & \text { Microwave power } \\ 1 & 10 \mathrm{~min} & 200^{\circ} \mathrm{C} & \text { Up to } 1000 \mathrm{Watt}^{*} \\ 2 & 20 \mathrm{~min} & 200^{\circ} \mathrm{C} & \text { Up to } 1000 \mathrm{Watt}^{*}\end{array}$




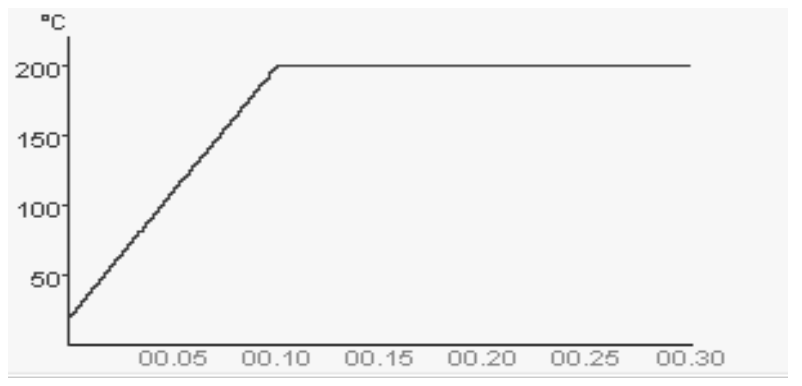

Fig. 1. Temperature profile.

After cooling to room temperature, Open the vessel and filter through whatman paper no. 1 into $25 \mathrm{ml}$ volumetric flask and dilute with deionised water. Prepare the reagent blank as in sample preparation but without adding the sample. Digested samples were analyzed for mercury, cadmium, titanium, bismuth, lead, arsenic and thallium using Inductive coupled plasma - Optical emission spectrometer.

\section{Calibration curve}

The 1000 ppm standard solutions of elements were diluted in five different concentrations to obtain calibration curve for quantitative analysis (Fig. 2). All the measurements were run in triplicate for the sample and standard solutions.

Intensity

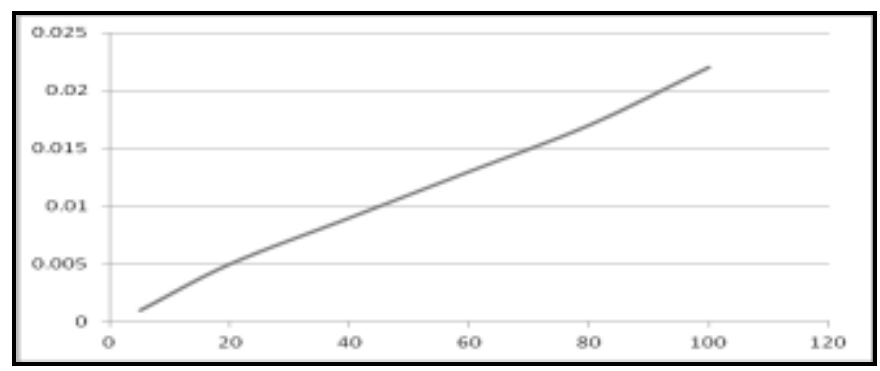

Fig. 2. Calibration curve of mercury.

\section{Calculations}

Use the following equation to calculate the concentration of elements in $\mathrm{mg} / \mathrm{Kg}=\mathrm{ppm}$

Concentration $\mathrm{mg} / \mathrm{Kg}=($ Concentration $\mathrm{mg} / \mathrm{l} \times$ volume $\mathrm{ml} \div$ weight $\mathrm{gm}){ }^{(25)}$. Table 1 .

The concentration of heavy metals content in cosmetic products are listed in

Recovery, standard deviation $(S)$, relative standard deviation $(R S D)$ and variation $\left(S^{2}\right)$

The method of standard addition ${ }^{(26)}$ which is considered as a validation method was used to demonstrate the validity of our method. Hence, a recovery test was performed using method of standard addition. Standard solutions containing $\mathrm{Hg}, \mathrm{Cd}, \mathrm{Ti}, \mathrm{Bi}, \mathrm{Pd}, \mathrm{AS}$ and $\mathrm{Tl}$ were prepared and spiked with digested

Egypt. J. Chem. 58, No. 3 (2015) 
sample, after dilution of sample to $25 \mathrm{ml}{ }^{(26)}$. Percent recovery of $\mathrm{Hg}, \mathrm{Cd}, \mathrm{Ti}, \mathrm{Bi}$, $\mathrm{Pb}, \mathrm{As}$ and $\mathrm{Tl}$ from last table ranged from $88.52 \%$ to $99.62 \%$. (Table 2).

TABLE 1. Calibration standard units and concentrations by ICP.

\begin{tabular}{|c|c|c|c|c|}
\hline Analyte & Calibration units & Calib Std1 & Calib Std2 & Calib Std3 \\
\hline $\mathrm{Hg} 546.074 \mathrm{~nm}$ & $\mathrm{mg} / \mathrm{L}$ & & $10: 000$ & \\
\hline Cd 226.502nm & $\mathrm{mg} / \mathrm{L}$ & & & $10: 00$ \\
\hline Ti 337.279nm & $\mathrm{mg} / \mathrm{L}$ & & & $10: 00$ \\
\hline Bi 190.171nm & $\mathrm{mg} / \mathrm{L}$ & $10: 00$ & & \\
\hline $\mathrm{Pb} \mathrm{261.418nm}$ & $\mathrm{mg} / \mathrm{L}$ & & & $10: 00$ \\
\hline As $188.979 \mathrm{~nm}$ & $\mathrm{mg} / \mathrm{L}$ & & & $10: 00$ \\
\hline Tl $190.801 \mathrm{~nm}$ & $\mathrm{mg} / \mathrm{L}$ & & & $10: 00$ \\
\hline
\end{tabular}

TABLE 2. Recovery, S, RSD and $\mathrm{S}^{2}$.

\begin{tabular}{|c|c|c|c|c|c|c|}
\hline Element & $\begin{array}{c}\text { Spiked } \\
\text { amount } \\
\text { ppm }\end{array}$ & $\begin{array}{c}\text { Measured } \\
\text { amount } \\
\text { ppm }\end{array}$ & $\begin{array}{c}\text { Recovery } \\
\text { \% }\end{array}$ & $\mathbf{S}$ & $\begin{array}{c}\text { RSD } \\
\text { \% }\end{array}$ & $\mathbf{S}^{\mathbf{2}}$ \\
\hline $\mathrm{Hg}$ & 5 & 4.458 & 89.16 & 0.434 & 9.734 & 0.188 \\
\hline $\mathrm{Cd}$ & 5 & 4.898 & 97.96 & 0.035 & 0.716 & 0.001 \\
\hline $\mathrm{Ti}$ & 5 & 4.898 & 97.96 & 0.192 & 3.943 & 0.036 \\
\hline $\mathrm{Bi}$ & 5 & 4.426 & 88.52 & 0.009 & 13.724 & 0.0001 \\
\hline $\mathrm{Pb}$ & 5 & 4.981 & 99.62 & 0.075 & 1.497 & 0.006 \\
\hline $\mathrm{As}$ & 5 & 4.793 & 95.86 & 0.039 & 0.808 & 0.002 \\
\hline $\mathrm{Tl}$ & 5 & 4.816 & 96.32 & 0.025 & 0.510 & 0.001 \\
\hline
\end{tabular}

\section{Results and Discussion}

Contents of heavy elements in the screened samples as a mean of triplicate determination are described in Table 3. Mercury concentration was varied along eight samples from 18.57 to 5739.16 ppm, sample B6 was the highest mercury concentration and sample B8 was the lowest. Mercury was also found below detectable limit in total eight samples. According to the WHO ${ }^{(27)}$, the permissible limit for mercury in cosmetic is $1 \mathrm{ppm}$.

In that way, eight samples B1, B3, B4, B5, B6, B7 and B11 were found to contain mercury concentration above permissible limit. The cadmium concentrations varied from 0.06 to $0.57 \mathrm{ppm}$ on 12 samples. Concentrations of cadmium were comparable in samples B4 and B13 which have the lowest, while $\mathrm{B} 12$ have the highest cadmium concentration. According to the WHO ${ }^{(27)}$, the permissible limit for cadmium in cosmetic is $0.3 \mathrm{ppm}$. Whereas, the three samples B7, B8 and B12 were found to contain cadmium concentration above permissible limit. Five samples having bismuth contents between 0.70 and $7013.53 \mathrm{ppm}$, they must be blend. Bismuth found below detectable limit in total eleven samples. The lead concentrations varied from 6.93 to $456.70 \mathrm{ppm}$, sample B3 has the highest and sample B6 has the lowest while eight samples were found 


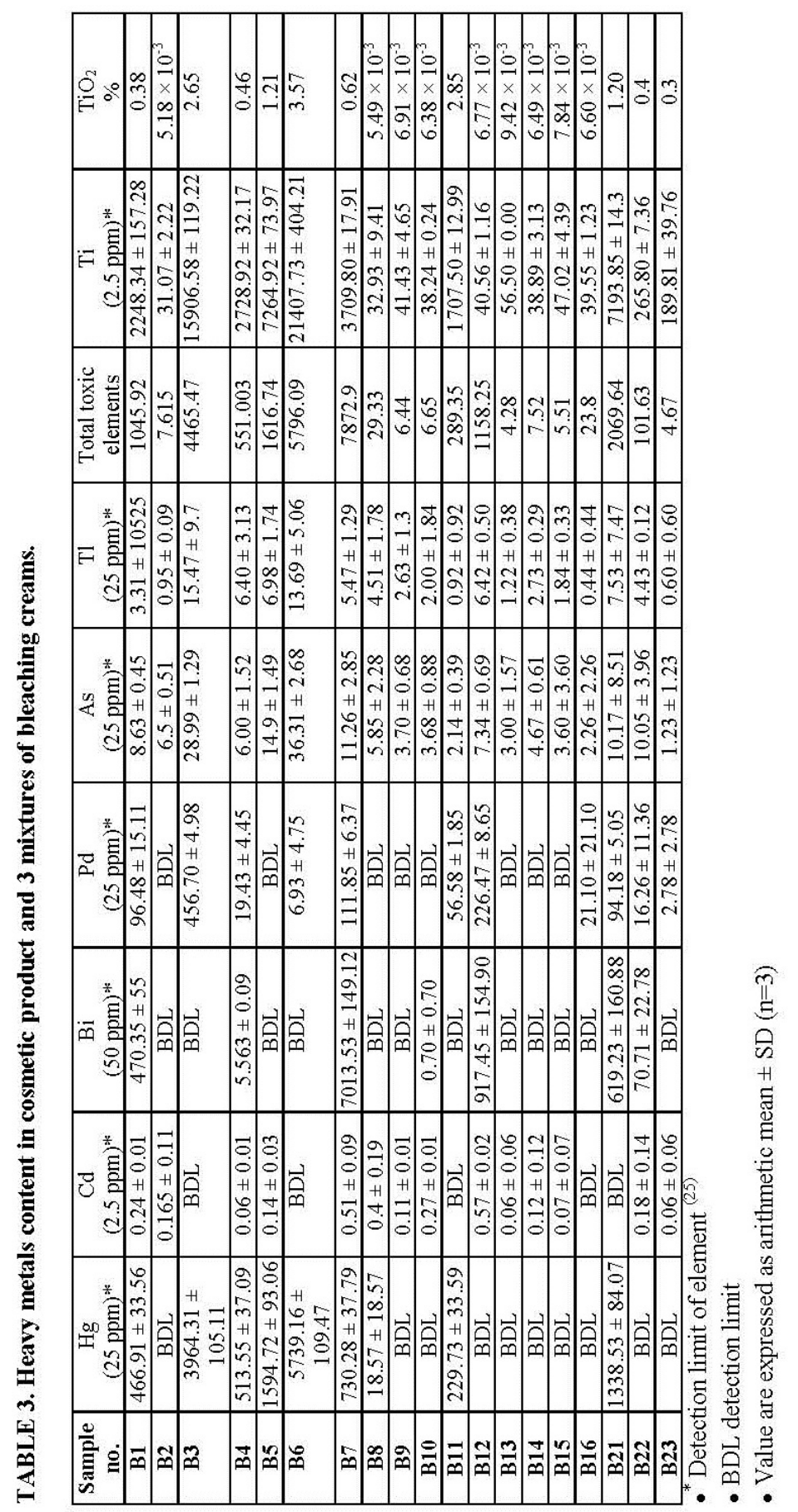

Egypt. J. Chem. 58, No. 3 (2015) 
below detectable limit. According to the $\mathrm{WHO}^{(27)}$, the permissible limit for lead in cosmetic is $10 \mathrm{ppm}$. In that way, six samples B1, B3, B4, B7, B11 and B12 were found to contain lead concentration above permissible limit. Arsenic was found on all samples in small quantities varied from 2.14 to $36.31 \mathrm{ppm}$. Sample B6 has the highest and sample B11was the lowest. According to the WHO (27), the permissible limit for arsenic in cosmetic is $10 \mathrm{ppm}$. The four samples B3, B5, B6 and B7 were found to contain arsenic concentration above permissible limit. Also, thallium was found on all samples in small quantities varied from 0.44 to 15.47 ppm. Sample B7 has the highest and sample B10 was the lowest. All sixteen samples have different titanium concentrations varied from 31.07 to 21407.73 ppm, sample B6 has the highest titanium concentration and sample B2 was the lowest. Titanium presents as titanium dioxide in cream matrix, $\mathrm{TiO}_{2} \%$ varied from $5.18 \times 10^{-3}$ to $3.57 \%$, so all cream products under investigation accumulated this compound at a level appreciably below the permissible limit $25 \%$ according to the $(\mathrm{SASO} / / 1953 / 2005)^{(22)}$. The total toxic metals concentrations on creams up to $1000 \mathrm{ppm}$ were found in 6 samples (B1, B3, B5, $\mathrm{B} 6, \mathrm{~B} 7$ and $\mathrm{B} 12)$ which varied from 1045.92 to $7872.9 \mathrm{ppm}$. Bleaching mixture no. 21 consists of $\mathrm{B} 1+\mathrm{B} 2+\mathrm{B} 3+\mathrm{B} 4+\mathrm{B} 5+\mathrm{B} 6+\mathrm{B} 7+\mathrm{B} 7$ creams, it has $1338.53 \mathrm{ppm} \mathrm{Hg}, 619.23 \mathrm{ppm} \mathrm{Bi}$ and $94.18 \mathrm{ppm} \mathrm{Pb}$, (collecting result of elements concentration in creams) this mixture was above permissible limits and must be blended. Bleaching mixture no. 22 consists of $\mathrm{B} 2+\mathrm{B} 8+\mathrm{B} 9+\mathrm{B} 10+$ $\mathrm{B} 11+\mathrm{B} 12+\mathrm{B} 16$ creams, it has $70.71 \mathrm{ppm} \mathrm{Bi}$ and $16.26 \mathrm{ppm} \mathrm{Pb}$, also according to $\mathrm{WHO}^{(27)}$ it must be blind. Bleaching mixture no. 23 consists of B13 + B14 + B15 + B16 creams, it has small quantities of different elements under permissible limits, so it is not blended.

\section{Conclusion}

In the present study, we determined 7 heavy metals $(\mathrm{Hg}, \mathrm{Cd}, \mathrm{Ti}, \mathrm{Bi}, \mathrm{Pd}, \mathrm{AS}$ and $\mathrm{Tl}$ ) in 16 bleaching creams and 3 mixtures of bleaching creams. Based upon the results, we concluded that mercury, bismuth and lead are present in high quantities in samples, they ranged from no detected to $7013.53 \mathrm{ppm}$, however both arsenic and thallium present in small quantities ranged from 0.44 to 36.31 ppm. $\mathrm{TiO}_{2}$ determined under the permissible limit of SASO. Two of bleaching mixtures have high quantities of total heavy metals up to the permissible limit. The continued use of products contaminated with such heavy metals may cause slow release of these metals into the human body and thus show their harmful effects. So the extensive uses of such products should be avoided. The satisfactory results show that the method is quick, accurate, sensitive, convenient and effective. Removal of heavy metals from personal care products after manufacture is not possible, however if careful selection of the raw material is made keeping in view the heavy metal contents we can improve the quality of the products and save the beauty of the environment. This research project will attract people to select human friendly products. Also, it attracts people's attention to how mixing more than one bleaching cream on use, about double dangers result due to double concentration of heavy metals in mixtures. 


\section{References}

1. Brown, V.J., Metals in lip products: A cause for concern. Environ. Health Perspect. 121, 196 (2013).

2. Al-Dayel, O., Hefne, J. and Al-Ajyan, T., Human exposure to heavy metals from cosmetics. Orient. J. Chem. 27 (1), 01-11 (2011).

3. Chauhan, A.S., Bhadauria, R., Singh, A.K., Lodhi, S.S., Chaturvedi, D.K. and Tomari, V.S., Determination of lead and cadmium in cosmetics products. J. Chem. Pharm. Res. 2 (6), 92-97 (2010).

4. Sainio, E.L., Jolanki, R., Hakala, E. and Kanerva, L., Metals and arsenic in eye shadows. Contact Dermatitis, $\mathbf{4 2}$ (1), 5-10 (2000).

5. Grosser, Z., Davidowski, L. and Thompson, L., The Determination of Metals on Cosmetics, PerkinElmer, Inc.Sheton, CT 06484 USA, accessed 1-14 (2011).

6. Nnorom, I.C., Igwe, J.C. and Oji-Nnorom, C.G., Trace metal contents of facial (make-up) cosmetics commonly used in nigeria. Afr. J. Biotechnol. 4 (10), 1133-1138 (2005).

7. Saeed, M., Muhammad, N., Khan, H. and Khan, S.A., Analysis of toxic heavy metals in branded Pakistani herbal products. J. Chem. Soc. Pak. 32, 471-475 (2010).

8. Barakat, M.A., New trends in removing heavy metals from industrial wastewater. Arab. J. Chem. 4, 361-377 (2011)

9. Adal, A. and Tarabar, A., Heavy Metal Toxicity (2013) http://emedicine. medscape.com/article/814960-overview.

10. Al-Trabulsy, H.A.M., Khater, A.E.M. and Habani, F.I., Heavy elements concentrations, physicochemical characteristics and natural radio nuclides levels along the Saudi coastline of the Gulf of Aqaba. Arab. J. Chem. 6, 183-189 (2013).

11. Glanze, W.D., Louis, S. and Mosby, C.V., Mosby Medical Encyclopedia, Revised edition (1996).

12. Pachauri, V. and Flora, S.J.S., Chelation in metal intoxication. Int. J. Environ. Res. Public Health. 7 (7), 2745-2788 (2010).

13. CDC, Centers for Disease Control and Prevention, Second National Report on Human Exposure to Environmental Chemicals (2003) http:// www. cdc.gov/ exposurereport/2nd/.

14. Farr, G., The hair tissue mineral analysis/why heavy metals are a hazard to your health, Updated 31Dec, (2009).

15. Ayenimo, J.G., Yusuf, A.M., Adekule, A.S. and Makinde, O.W., Heavy metal exposure from personal care product. Bull. Environ. Contam. Toxicol. 84, 8-14 (2010).

Egypt. J. Chem. 58, No. 3 (2015) 
16. Theresa, O.C., Onebunne, O.C., Dorcas, W.A. and Ajani, O.I., Potentially toxic metals exposure from body creams sold in Lagos. Nigeria. Researcher, 3 (1), 30-37 (2011).

17. Gawkrodger, D. J., Occupational skin cancers. Occupational Medicine, 54 (7), 458-463 (2004).

18. Jarup, L, Hazards of heavy metal contamination. Br. Med. Bull., 68, 167-182 (2004).

19. US FDA, United State Food Drug \& Cosmetic Act on Hazardous Chemicals in Cosmetics. Available at: <http://www.fda.gov/opacom/laws/fdcact/fdctoc.htm>.

20. Draft Guidance on Heavy Metals in Cosmetics, Health Canada, http://www.hcsc.gc.ca/cps-spc/legislation/consultation/_cosmet/metal-metaux-consult-eng.php (accessed 1-24-2011).

21. Cosmetic Products Regulation, EU Regulation 1223/2009 (accessed 1-24-2011).

22. Saudi Standards, Metrology and Quality Organization, Cosmetic Products - the cosmetic products (safety) regulations 1953, Riyadh: SASO (2005).

23. Olsen, P., Bismacine, (2006) access date 5/6/2010, http://www.fda. gov/bbs/ topics /news /2006/ new01415.html.

24. Hepp, N. M., Mindak, W. R., and Cheng, J., Journal of Cosmetic Science, 60 (4), July/August (2009).

25. Charles, B. and Kemeth, J., Concept, Instrumentation and Techniques in Inductively Coupled Plasma Optical Emission Spectrometry, PerkinElmer,Inc. third edition (2004).

26. Zamil, E, Analytical Chemistry - Instrumental Analysis, Elkhraji library, first edition (1988).

27. WHO. Environmental Health Criteria: International Programme on Chemical Safety. World Health Organization, Geneva pp 165 (1995).

(Received 29/12/2014; accepted $6 / 5 / 2015)$ 


\title{
تقدير المعـادن الثقيلـة في 17 كريم تبيضيض و r مخـاليط لكريمـات \\ التبييض المتواجدة بالسوق السعودية النية
}

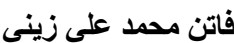 \\ قنسم الكيمياء ـ كلية التعلوم بفرع الفيصلية ـ جامعة الملاك عبد العزيز - جدة ـ المملكة

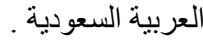

\begin{abstract}
المعـادن الثقيلة في منتجـات كريمـات تبيضيض البشـرة تسبب العديد مـن المشــلكل

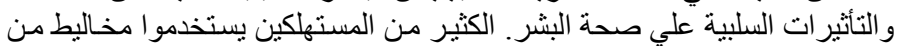

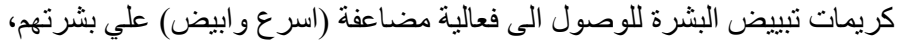

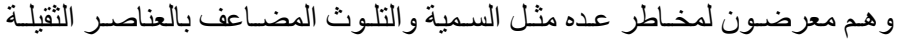

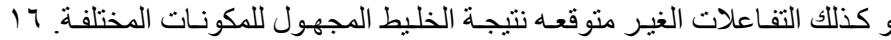

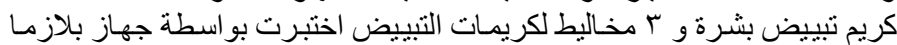

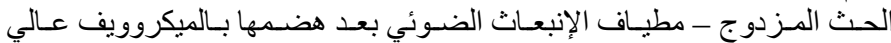

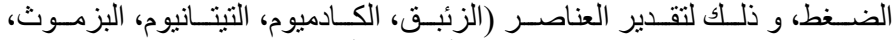

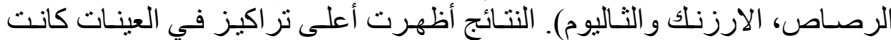

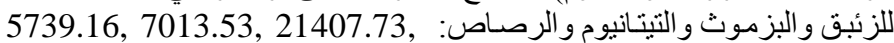

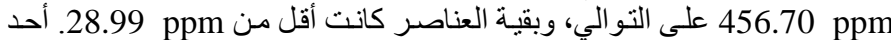

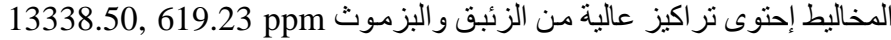

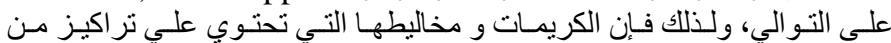

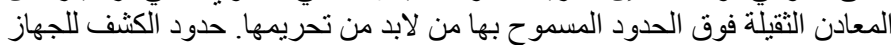

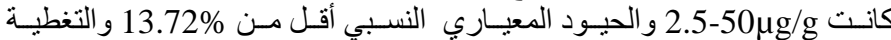
للمستحضر ات في حدود 99.62\% to 28.52 to

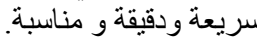

